\title{
Effects of vitamin $C$ on glucose metabolism during acute Chagas disease
}

\author{
Efeitos da vitamina $C$ no metabolismo da glicose \\ durante a doença de Chagas aguda
}

Julia Castanheira ${ }^{\mathrm{I}}$

Renata Facina Santos ${ }^{\text {II }}$

Letícia Alvetti ${ }^{\mathrm{I}}$

Roberto Castanho ${ }^{\mathrm{I}}$

HAMILTON Rocha JUNIOR ${ }^{\text {III }}$

Altino Therezo ${ }^{1}$

Eduardo Chagas ${ }^{1}$

Luciamare Perinetti Alves

MARTINS $^{1}$

IFaculdade de Medicina de Marília

(FAMEMA), Marília/SP - Brasil

"Hospital Lauro de Souza Lima,

Bauru/SP - Brasil

"IIHospital Madre Teodora, Campi-

nas/SP - Brasil

\begin{abstract}
Introduction: Chagas disease is characterized by lesions caused by the host immune response, which can influence the glucose metabolism. Objective: To evaluate the action of vitamin C on glucose metabolism during the acute phase of Chagas disease. Methods: Sixty Swiss mice were divided into four groups: NW, NC, IW, and IC. NW and NC groups were not infected, whereas IW and IC were intraperitoneally infected with $5.0 \times 10^{4}$ trypomastigotes of T. cruzi QM2 strain. IC and NC groups received $500 \mathrm{mg}$ /day of vitamin C. All groups were treated for 60 days. Blood glucose and weight were measured individually and weekly. Five animals from each group were euthanized on day 15, 30, and 60 for blood and tissues collection. Results: Lower parasitemia $(\mathrm{p} \leq 0.05)$ in the IC group was noticed, but greater damage to the pancreatic tissue. In the 15 days post infection, lower glucose concentrations $(\mathrm{p} \leq 0.05)$ and insulin levels $(\mathrm{p} \leq 0.05)$ were observed in the IC and IW groups regarding NC and NW. The infected groups had decreased body mass 30 days post infection, with significant difference $(\mathrm{p} \leq 0.05)$ in the IW group on the sixtieth day. Significant difference $(\mathrm{p} \leq 0.05)$ for hepatic glycogen was found only on day 60 , with a lower concentration in the NC group than the other groups.

Conclusion: The use of vitamin C can cause positive physiological repercussions in Chagas disease by controlling parasitemia, blood glucose and weight 30 days after infection. However, these repercussions can be negative for intensifying the inflammatory process.
\end{abstract}

Key words: Trypanosoma cruzi. Blood glucose. Vitamin C. Weight loss. Cachexia. Chagas disease.

Resumo - Introdução: A doença de Chagas é caracterizada por lesões causadas pela resposta imune do hospedeiro, podendo influenciar o metabolismo da glicose. Objetivo: Avaliar a ação da vitamina $\mathrm{C}$ no metabolismo da glicose na fase aguda da doença de Chagas. Métodos: Sessenta camundongos Swiss foram divididos em quatro grupos: NW, NC, IW e IC. Os grupos NW e NC não foram infectados, enquanto IW e IC foram infectados intraperitonealmente com 5,0 $\times 10^{4}$ tripomastigotas da cepa QM2 de T. cruzi. Os grupos IC e NC receberam 500 $\mathrm{mg} /$ dia de vitamina C. Todos os grupos foram tratados por 60 dias. Glicemia e o peso foram aferidos individualmente e semanalmente. Cinco animais de cada grupo foram eutanasiados nos dias 15, 30 e 60 para coleta de sangue e tecidos. 
Resultados: Observou-se menor parasitemia $(\mathrm{p} \leq 0,05)$ no grupo IC, entretanto maior dano ao tecido pancreático. Nos 15 dias pós-infecção, menores concentrações de glicose $(\mathrm{p} \leq 0,05)$ e níveis de insulina $(\mathrm{p} \leq 0,05)$ foram observados nos grupos IC e IW em relação a NC e NW no $15^{\circ}$ dia pós-infecção. Os grupos infectados apresentaram diminuição da massa corporal 30 dias pós-infecção, com diferença significativa $(\mathrm{p} \leq 0,05)$ no grupo IW no sexagésimo dia. Diferença significativa $(\mathrm{p} \leq 0,05)$ para $o$ glicogênio hepático foi encontrada apenas no dia 60 , com concentração menor no grupo $\mathrm{NC}$ em relação aos demais grupos. Conclusão: $\mathrm{O}$ uso da vitamina $\mathrm{C}$ pode causar repercussões fisiológicas positivas na doença de Chagas ao controlar a parasitemia, glicemia e peso30 dias após a infecção. Porém, essas repercussões podem ser negativas por intensificar o processo inflamatório.

Palavras-chave: Trypanosoma cruzi. Glicemia. Vitamina C. Perda de peso. Caquexia. Doença de Chagas.

\section{INTRODUCTION}

Chagas disease, caused by the protozoan Trypanosoma cruzi, is still a public health issue problem in South America and is the third neglected infection among those transmitted by vectors. ${ }^{1}$ Due to intense immigration, it has become a globalized disease. ${ }^{2}$

The infection happens after inoculation of the infective form metacyclic trypomastigote by the insect vector or by it's ingestion. Other transmission forms can also occur such as blood transfusion, breastfeeding or laboratory accidents. Currently, oral transmission is the most important form of transmission. $^{3}$

After penetration into vertebrate hosts, trypomastigotes differentiate intracellularly into amastigotes, a replicative form of the parasite. In this intracellular form, the immune system recognizes the infected cell through epitopes of the parasite. Thus, $\mathrm{CD} 8+$ cytotoxic $\mathrm{T}$ lymphocytes recognize the parasite antigens, controlling its replication and destroying the infected cell, with the participation of natural killer cells. Inflammatory cytokines, such as interferon gamma (INF- $\gamma$ ) and tumor necrosis factor alpha (TNF- $\alpha$ ), can activate phagocytes and produce oxidant substances, like nitric oxide (NO), which reduces but does not eliminate the parasite. ${ }^{4}$

Thus, the susceptible host triggers an inflammatory response with the production of reactive oxygen species (ROS) leading to oxidative stress, caused by an excessive generation of free radicals or failure to remove these species. ${ }^{5}$ This oxidative stress can influence several processes, like an increased resistance to insulin ${ }^{6}$, suggesting that some metabolic parameters can be altered in the host.

Several human and experimental studies have shown functional and anatomical impairment of the pancreas, both in the acute and chronic phases of Chagas disease. ${ }^{7,8}$ Inflammatory process with focal or diffuse pancreatitis, insulitis and neuritis were noticed in hamsters by Santos et al. $(2004)^{7}$ in the acute phase and Saldanha et al. $(2001)^{8}$ reported changes in three pancreas fragments with increase of pancreatic islets, in- 
flammatory infiltrate and fibrosis in chronic patients with Chagas disease.

Studies have found that chagasic patients had elevated blood glucose levels and the greater predisposition to develop type 2 diabetes mellitus (DM2) compared to healthy individuals. ${ }^{9,10}$ However, other studies have not observed a higher prevalence of diabetes mellitus or changes in oral glucose tolerance test in chagasic patients ${ }^{11,12}$ or in the insulin resistance index. ${ }^{13}$

Research conducted by Tanowitz et al. $(1988)^{14}$ demonstrated that diabetic rats infected with T. cruzi had increased parasitemia. On the other hand, Nagajyothi et al. ${ }^{15,16}$ reported that mice infected with $T$. cruzi had hypoglycemia in the acute phase with inflammation and parasitism being detected in pancreas at 15 days post infection. Coombs et al. (2005) ${ }^{17}$ also found that insulin levels decreased in the acute phase of $T$. cruzi infection in rats, as a response to very low glucose levels at this stage of the disease; which in many cases is a predict factor of mortality.

Glucose blood control may be influenced by vitamin $\mathrm{C}$ supplementation, and some studies ${ }^{18,19}$ have reported that elevated plasma levels of ascorbic acid delayed insulin response to changes in glucose levels in normoglycemic individuals prolonging prandial hyperglycemia. ${ }^{20}$ On the other hand, the interrelation between these factors is complex, since the concentrations of vitamin $\mathrm{C}$ in an organism depend not only on ingestion, but also on blood glucose and plasma insulin concentrations. ${ }^{21}$

Thus, this research aimed to evaluate the action of vitamin $\mathrm{C}$ in glucose metabolism and inflammatory process in pancreas and liver during the evolution of experimental acute Chagas disease.

\section{Methods}

\section{Experimental animals}

This study used 60 male Swiss mice, 25 days old with average weight ranging from 20 to 25 grams, which were sourced from the Central Animal Facility of Marília Medical School (Famema). These animals were randomly divided into 4 groups of 15 animals, and each group was subdivided into three batches of five animals, which were analyzed at 15-, 30-, and 60-days post infection. At the end of each experimental period, the animals were euthanized in a $\mathrm{CO}_{2}$ chamber to collect blood and tissues.

The animals were kept in collective cages with 5 animals each at the Animal Experimentation Bioterio of Parasitology Department of Marilia Medical School, with temperature stabilized at $24^{\circ} \mathrm{C}$ and a 12-hour dark light cycle, receiving Nuvilab ${ }^{\circledR}$ ration and water or supplemented water depending on which subgroup they belonged. The treatment, care, and euthanasia of the mice followed CEUA standards. The project was approved by CEUA-Famema under $n^{\circ}$ 390/16.

\section{Experimental groups}

The animals of the infected groups were inoculated intraperitoneally with $5.0 \times 10^{4}$ trypomastigote forms of T. cruzi QM2 strain ${ }^{22}$ with blood from another previously infected mouse, and the mice from the non-infected groups were considered placebo. The groups of animals were classified as IC: Infected with T. cruzi QM2 strain and treated with vitamin 
C; IW: Infected with T. cruzi QM2 strain and treated with water; NC: Non-infected with $T$. cruzi QM2 strain and treated with vitamin C; NW: Non-infected with T. cruzi QM2 strain and treated with water.

\section{Treatment}

The IC and NC groups were treated with ascorbic acid in a dosage equivalent to $500 \mathrm{mg} /$ day vitamin $\mathrm{C}$ for a human body mass of $70 \mathrm{~kg}$. Thus, considering that mice average weight was approximately $23 \mathrm{~g}$, each mouse received $7.14 \mathrm{mg} / \mathrm{kg} /$ day. Therefore, $0.5 \mathrm{ml}$ of Cewin ${ }^{\circledast}$ drops were diluted in 3.000 $\mathrm{ml}$ of water to obtain a concentration of $0.164 \mathrm{mg}$ in $5 \mathrm{ml}$ of water which is the mean ingested volume/day per mouse. The water cooler that served as a container for the supplemented water was wrapped in aluminum foil to avoid oxidation of vitamin $\mathrm{C}$ by light. The water and vitamin $\mathrm{C}$ solution was changed every 12 hours and this treatment was carried out for 60 days. The IW and NW groups received only water.

\section{Parasitemia study}

Blood was collected from the tail of each animal to parasitemia study, which was performed twice a week during the acute phase of the: infection in the IC and IW groups using the Brener method modified by Gusmão et al. ${ }^{23}$, starting on the seventh day post infection, until 60th day, with a total of 14 counts for each animal.

\section{Animal weighing}

The animals were weighed individually once a week on a BEL ${ }^{\circledast}$ semianalytic balance, model S 3102.

\section{Histopathological analysis}

Pancreas and liver fragments from the IC, IW, NC, NW groups were collected on day 15,30 , and 60 post infection, which were fixed in $10 \%$ formaldehyde solution ( $10 \%$ formaldehyde in $0.1 \mathrm{M}$ phosphate buffer, pH 7.2). After 48 hours, these fragments were washed in running water for 24 hours, dehydrated in 70\%, 80\%, 90\% and 100\% alcohol for one hour at each step. Afterwards the tissues were cleared in a solution of $100 \%$ alcohol and xylol (1:1) for 15 to 20 minutes dehydrated in ethanol, cleared in xylol, and encased in paraffin blocks. Five serial sections of $5 \mu \mathrm{m}$ thickness were rehydrated and stained with hematoxylin-eosin (H\&E). All of them were analyzed in their whole extension in an Olympus BX41 microscope coupled with an Olympus DP-25 digital video camera. The figures were captured by Cell Sens by Dimension software, Olympus. Table 1 show the graduation and classification of the inflammatory process, amastigotes nests, and areas of necrosis based on studies by Lopes and Prado Jr. $(2007)^{24}$.

\section{Blood glucose determination}

Blood was collected from the tail of each mice to glucose determination, which was performed weekly after a five-hour food fast, using the Advantage ${ }^{\circledast}$ monitor, with its respective tapes.

\section{Insulinemia determination}

Blood for insulinemia determination was collected by cardiac puncture using heparin as an anticoagulant, which was performed after a five-hour food fast 25 at 15-, 30-, and 60-days post infection, using 
Table 1. Graduation and classification of the inflammatory process, amastigotes nests, and areas of necrosis

\begin{tabular}{|c|c|c|c|}
\hline Graduation & Inflamatory process & Amastigotes nests & Necrosis \\
\hline zero & Absence of inflamation & $\begin{array}{l}\text { Absence of amastigotes } \\
\text { nests }\end{array}$ & Absence of necrosis \\
\hline+ & $\begin{array}{l}\text { Mild inflammation } \\
\text { (less than } 12.5 \% \text { of the } \\
\text { fields) }\end{array}$ & $\begin{array}{l}\text { Only one amastigote } \\
\text { nest }\end{array}$ & $\begin{array}{l}\text { Only one focus of } \\
\text { necrosis }\end{array}$ \\
\hline++ & $\begin{array}{l}\text { Moderate inflammation } \\
\text { ( } 25 \text { to } 50 \% \text { of the fields) }\end{array}$ & Two amastigote nest & Two foci of necrosis \\
\hline+++ & $\begin{array}{l}\text { Intense inflammation } \\
\text { ( } 50 \text { to } 100 \% \text { of the } \\
\text { fields) }\end{array}$ & $\begin{array}{l}\text { Three or more } \\
\text { amastigotes nest }\end{array}$ & $\begin{array}{l}\text { Three or more foci } \\
\text { of necrosis }\end{array}$ \\
\hline
\end{tabular}

a ELISA kit for Rat/Mouse INSULIN from Mercodia $^{\circledast}$ (Sweden).

Evaluation of Peripheral Insulin Sensitivity by Model "Quantitative Insulin Sensitivity Check Index"(QUICKI) ${ }^{26}$

Peripheral Insulin Sensitivity was evaluated considering a relation between insulin and glycemia in the fasted state, with the following formula: QUICKI $=1 /(\log$ Insulin + Log Glucose)

\section{Hepatic glycogen determination}

Liver fragments from all the IC, IW, NC, NW groups was collected at 15-, 30-, and 60-days post infection, and their weight were obtained on an analytical balance Q500L210C (Quimis ${ }^{\circledR}$ ).

Glycogen extraction was performed by liver digestion in a $\mathrm{KOH}(6 \mathrm{~N})$ solution, at a temperature of $100^{\circ} \mathrm{C}$ and precipitation with ethanol (95\%). ${ }^{27}$ After this procedure, $10 \%$ of $\mathrm{K}_{2} \mathrm{SO}_{4}$ was added to the solution. The material was centrifuged at $700 \mathrm{~g}$, in a refrigerated centrifuge at $4^{\circ} \mathrm{C}$ for $3 \mathrm{~min}$, and $2.5 \mathrm{ml}$ of distilled water was added to the precipitate. The resulting solution was subjected to the phenol-sulfuric reaction and determined at $490 \mathrm{~nm}$.
The concentrations of the samples were obtained by comparison with a standard glucose control $(0.02 \%)$ from which hepatic glycogen concentrations ( $\mu \mathrm{mol}$ of glycosylglucose units of tissue-1) were calculated.

\section{Statistical analysis}

Data were described by mean and standard deviation (SD). The distribution of normality was verified by the Shapiro-Wilk test. The homogeneity of the variances was analyzed by the Levene test. The Mixed ANOVA of Repeated Measures was performed to analyze the effect of the group, time, and interaction group versus time. Pos-Hoc comparisons were performed by the Boferroni test. Under conditions where the normality distribution and homogeneity of variances were violated, a nonparametric Friedman test was performed to analyze the effect of time within each group followed by pairwise comparisons by the Mann -Whitney test when necessary and non-parametric Kruskal-Wallis test to analyze group effect within each time, followed by pairwise comparisons by the Wilcoxon test when necessary. For all analyzes, SPSS software 
version 19.0 for Windows was used, considering the significance level of $5 \%$.

\section{RESULTS}

The evolution of the parasitemia during the acute phase (Figure 1) showed that animals in group IW presented lower initial parasitemia in relation to the IC group, but beginning on the tenth day, the multiplication of the trypomastigotes increased in group IW in relation to IC with a statistically significant difference on the fif- teenth day $(\mathrm{p} \leq 0.05)$ by the nonparametric Mann-Whitney test. With the disease progression, the animals of the IC group developed parasitemia with lower values than group IW until day 25, when the peak of the parasitemia was also significantly different $(\mathrm{p} \leq 0.05)$. From this period, blood trypomastigotes decreased in both groups, with significant differences at day 55 and gradual decrease until day 60 , indicating the beginning of the chronic phase for both groups. No animals died during the performance of parasitemic curve.

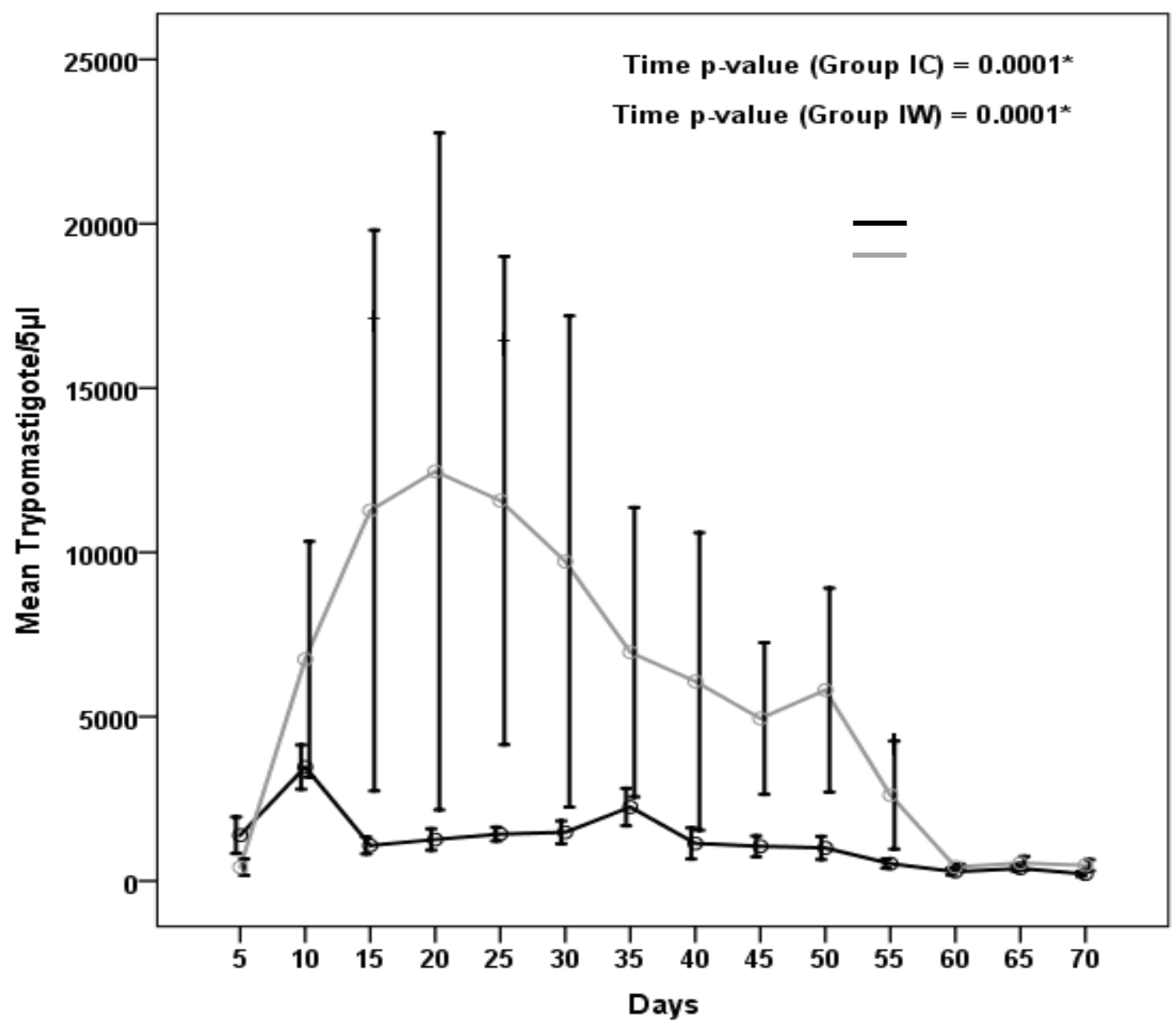

Figure 1. Parasitemia curve determined by the average of the number of trypomastigotes $/ 5 \mu \mathrm{L}$ in the blood from the IW and IC groups. ${ }^{*} \mathrm{p} \leq 0.05$ significant time effect within the group for the non-parametric Friedman test; $\uparrow \mathrm{p} \leq 0.05$ significant difference in relation to the IC group within the time by the nonparametric Mann-Whitney test. 
The histopathological results showed that the IC group presented an inflammatory process in a greater number of animals than the IW group. No amastigote nests were found in the pancreas or liver, only inflammatory process, which in the pancreas was mostly discrete, localizing focally to the pancreatic interstitium without involvement of the islets of Langerhans (Figure 2). No inflammatory process was observed in the liver (Table 2).

Table2. Histopathological analysis of liver and pancreas at 15-, 30-, and 60-days post infection in mice infected with Trypanosoma cruzi QM2 strain and treated with vitamin C.

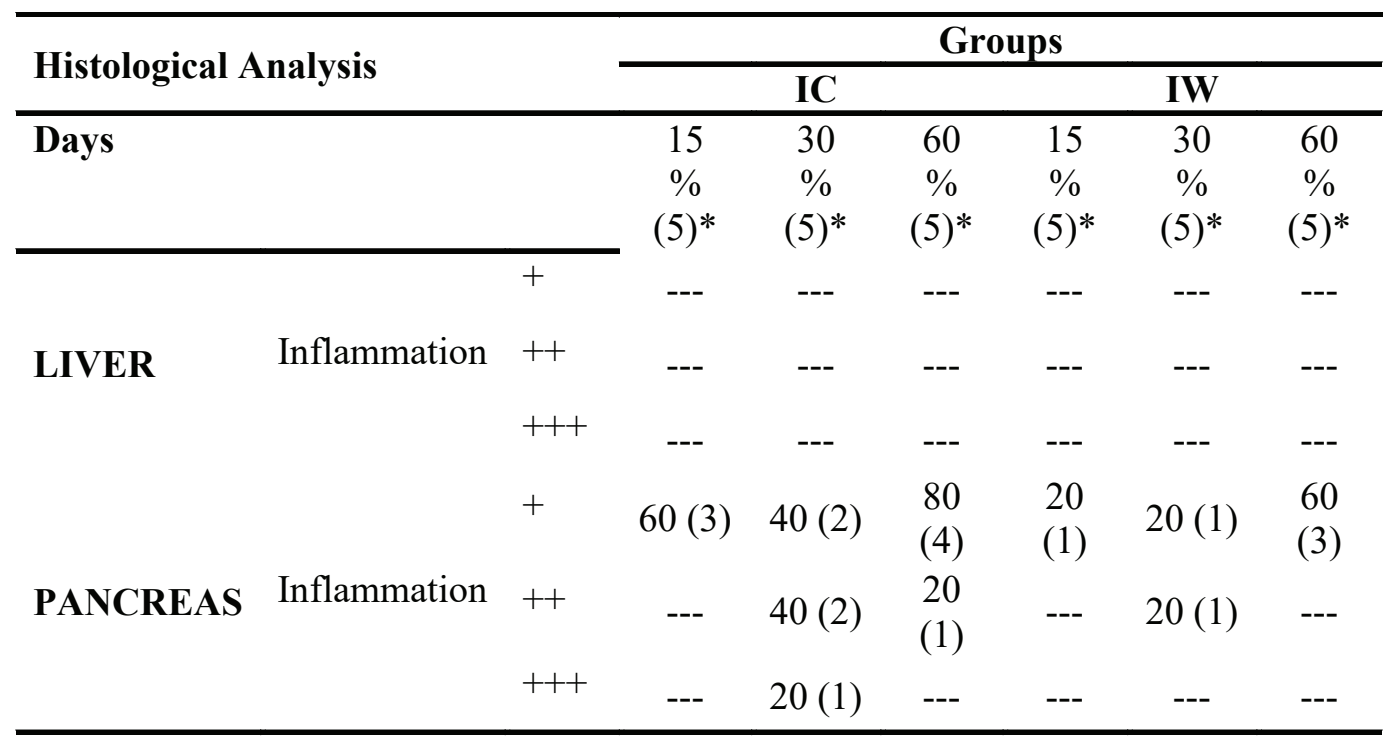
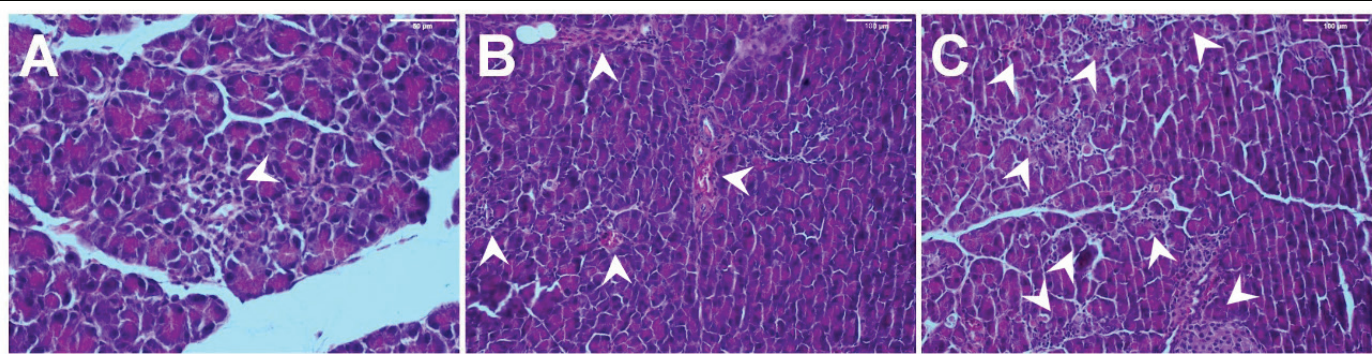

Figure 2. Histopathological aspects pointed by arrow heads illustrating parenchymal inflammation observed in pancreas of Swiss mice infected with Trypanosoma cruzi QM2 strain and treated with vitamin C. (A): Mild inflammatory process (+); (B): Moderate inflammatory process $(++)$; $(\mathrm{C})$ : Severe inflammatory process $(+++)$. 
Table 3 showed the hepatic glycogen, Insulin concentrations and QUICKI. No statistically significant difference was observed in hepatic glycogen concentration between days within each group. However, a significant difference was found at 60 days between the groups ( $\mathrm{p}=0.035$ ) with lower values in the NC group. Insulin concentration showed statistically significant difference between groups at $15(\mathrm{p}=0,009)$ and 30 days $(p=0,050)$ post infection. Insulin concentration was higher in groups NW and NC at15 days compared to groups IW and IC. On the 30th day, the NW group presented insulin values higher than the NC, IW and IC groups. In the NW $(\mathrm{p}=0.022)$ and IC (0.015) groups, higher insulin values were observed at 30 and 60 days compared to 15 days. In the NC group, insulin values at 60 days were higher than those observed at 15 to 30 days $(p=0.015)$. In the IW group, the insulin value at 30 days was higher than at 15 days $(\mathrm{p}=0.040)$.

For QUICKI, significant differences were observed between the groups at the time of 15 days $(\mathrm{p}=0.006)$ and 30 days $(\mathrm{p}=$ $0.049)$. At 15 days, the NW and NC groups had lower QUICKI values compared to the IW and IC groups. At 30 days, the NW group had QUICKI values lower than the NC and IW groups, but the IC group did not show significant differences in relation to any of the groups. Regarding the effect of time on QUICKI within the groups, a significant effect was found in the NW ( $\mathrm{p}=0.036), \mathrm{NC}$ $(\mathrm{p}=0.016)$ and IC $(\mathrm{p}=0.010)$ groups. In the NW group, higher QUICKI values were observed at 15 days compared to 60 days, and in the NC group, QUICKI values at 60 days were lower than those observed at 15 to 30 days. In the IC group, the QUICKI value at 15 days was higher than the values from 30 to 60 days.

All groups had gained weight by 15 days post infection in relation to the baseline, but at 30 days, the infected groups had decreased body mass, probably due to anorexia caused by high parasitemia in this period of infection, however, without a statistically significant difference in relation to the uninfected groups. On the sixtieth day, the IW group had decreased body mass, with significant results $(\mathrm{p} \leq 0.05)$ by ANOVA test in relation to the other groups (Figure 3A).

The glucose blood concentration was not significantly different between the baseline groups. After infection, with the beginning of parasitic multiplication, a decrease in blood glucose concentration was observed in the infected groups on day 15, with a statistically significant difference in relation to the uninfected groups $(\mathrm{p} \leq 0.05)$ by ANOVA test. At the end of the acute phase, glucose blood increased in all groups (Figure 3B). The absence of a statistically significant difference in blood glucose concentration between the uninfected control groups during the experiment demonstrated that the caramel solution used as the vehicle of Cewin ${ }^{\circledast}$ did not interfere with the results. 
Table 3. Mean and standard deviation (SD) of the values of Hepatic glycogen, Insulin, QUICKI between groups measured at 15-, 30- and 60-days post infection.

\begin{tabular}{|c|c|c|c|c|c|c|c|c|}
\hline & \multirow[b]{3}{*}{ GROUP } & \multicolumn{6}{|c|}{ Time } & \multirow[b]{3}{*}{ p-time } \\
\hline & & \multicolumn{2}{|c|}{15} & \multicolumn{2}{|c|}{30} & \multicolumn{2}{|c|}{60} & \\
\hline & & Mean & $\mathrm{SD}$ & Mean & SD & Mean & $\mathrm{SD}$ & \\
\hline \multirow{5}{*}{$\begin{array}{l}\text { Hepatic } \\
\text { glycogen } \\
\text { (g/100mg } \\
\text { of liver) }\end{array}$} & $\mathrm{NW}$ & 0.48 & 0.01 & 0.49 & 0.01 & $0.50^{b}$ & 0.06 & 0.662 \\
\hline & $\mathrm{NC}$ & 0.48 & 0.03 & 0.51 & 0.04 & $0.46^{\mathrm{a}}$ & 0.03 & 0.074 \\
\hline & IW & 0.54 & 0.08 & 0.49 & 0.02 & $0.56^{b}$ & 0.05 & 0.247 \\
\hline & IC & 0.49 & 0.03 & 0.50 & 0.02 & $0.50^{\mathrm{b}}$ & 0.02 & 0.819 \\
\hline & p-group & \multicolumn{2}{|c|}{0.512} & \multicolumn{2}{|c|}{0.519} & \multicolumn{2}{|c|}{$0.035 * *$} & \\
\hline \multirow{5}{*}{$\begin{array}{l}\text { Insulin } \\
\text { (pmol/L) }\end{array}$} & NW & $181^{\mathrm{a}}$ & 95 & $498^{\mathrm{a}^{\dagger}}$ & 121 & $532 \dagger$ & 221 & $0.022 *$ \\
\hline & $\mathrm{NC}$ & $166^{\mathrm{a}}$ & 65 & $281^{\mathrm{b}}$ & 82 & $657+$ & 300 & $0.015^{*}$ \\
\hline & IW & $64^{b}$ & 37 & $298^{\mathrm{b} \dagger}$ & 106 & 394 & 340 & $0.040 *$ \\
\hline & $\mathrm{IC}$ & $53^{b}$ & 28 & $328^{\mathrm{b} \dagger}$ & 97 & $422 \dagger$ & 195 & $0.015^{*}$ \\
\hline & p-group & \multicolumn{2}{|c|}{$0.009 * *$} & \multicolumn{2}{|c|}{$0.050 * *$} & \multicolumn{2}{|c|}{0.214} & \\
\hline \multirow[t]{5}{*}{ QUICKI } & NW & $0.29^{\mathrm{a}}$ & 0.03 & $0.25^{\mathrm{a}}$ & 0.01 & $0.25 \dagger$ & 0.02 & $0.036 *$ \\
\hline & $\mathrm{NC}$ & $0.29^{\mathrm{a}}$ & 0.01 & $0.28^{\mathrm{b}}$ & 0.01 & $0.25 \dagger+9$ & 0.01 & $0.016^{*}$ \\
\hline & IW & $0.35^{b}$ & 0.04 & $0.28^{b}$ & 0.03 & 0.30 & 0.08 & 0.076 \\
\hline & $\mathrm{IC}$ & $0.36^{\mathrm{b}}$ & 0.03 & $0.27 \dagger$ & 0.01 & $0.27 \dagger$ & 0.01 & $0.010 *$ \\
\hline & p-group & \multicolumn{2}{|c|}{$0.006 * *$} & \multicolumn{2}{|c|}{$0.049 * *$} & \multicolumn{2}{|c|}{0.074} & \\
\hline
\end{tabular}

Note: $* \mathrm{p} \leq 0.05$ significant effect of time within the group for the non-parametric Friedman test; $\uparrow \mathrm{p} \leq 0.05$ significant difference within the group in relation to the time of 15 days by the Wilcoxon non-parametric test; $\uparrow \mathrm{p} \leq 0.05$ significant difference within the group in relation to the time of 30 days by the Wilcoxon non-parametric test; $* * p \leq 0.05$ significant effect of the group within the time for non-parametric Kruskall-Wallis test. Different superscript letters indicate significant difference between groups for time by the nonparametric Mann-Whitney test. 

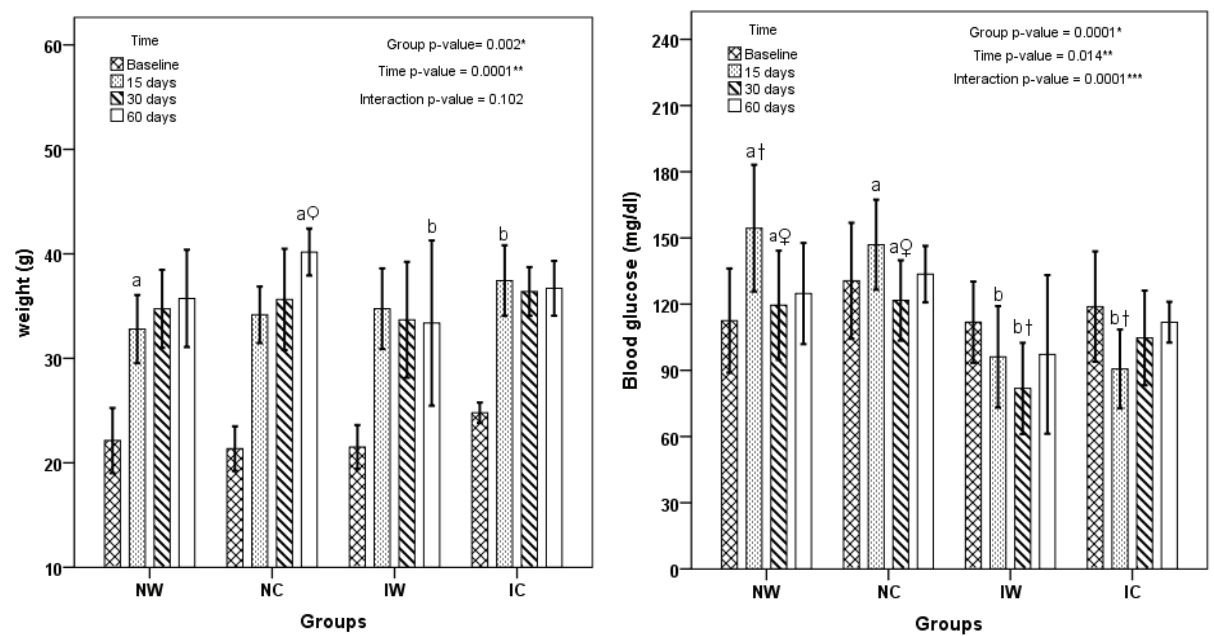

Figure 3. Mean values and standard deviation of weight and blood glucose during the acute phase of Chagas disease. A. ${ }^{*} p \leq 0.05$ significant effect of the group by the ANOVA test; $* * \mathrm{p} \leq 0.05$ significant effect of time by ANOVA test; $* * * \mathrm{p} \leq 0.05$ significant effect of group versus interaction time for the ANOVAtest. Different letters indicate significant differences between groups within each time by the Bonferroni Post-Hoc test; $+\mathrm{p} \leq 0.05$ significant difference within the group in relation at 15 days post infection by the Bonferroni Post-Hoc test. B. * $\mathrm{p} \leq 0.05$ significant effect of the group by the ANOVA test; ** $\mathrm{p} \leq 0.05$ significant effect of time by ANOVA test; *** $\mathrm{p} \leq 0.05$ significant effect of group versus interaction time for the ANOVA test. Different letters indicate significant differences between groups within each time by the Bonferroni PostHoc test; $\uparrow \mathrm{p} \leq 0.05$ significant difference within the group compared to Baseline by the Bonferroni Post-Hoc test; $+\mathrm{p} \leq 0.05$ significant difference within the group in relation at 15 days post infection by the Bonferroni Post-Hoc test.

Figure 3. Mean values and standard deviation of weight and blood glucose during the acute phase of Chagas disease.

\section{Discussion}

The infection trigged by $T$. cruzi is systemic and affect various organs including adipose tissue, pancreas and liver. ${ }^{15,16}$ Although the inflammatory process in the acute phase can affect the autonomous nervous system, causing parasympathetic denervation ${ }^{7}$, and dysruption of pancreatis islets, some authors have reported hypoglicemia in experimental studies. ${ }^{16}$

In an attempt to minimize this inflammatory process in Chagas disease, research of Maçao et al. (2007) ${ }^{28}$ have been carried out and showed that ascorbate could be favorable to the host. ${ }^{25,26}$ However, Duarte and Lunec $(2005)^{29}$ discussed the possible pro-oxidant role of vitamin $\mathrm{C}$. 
Our results demonstrated a clear effect of vitamin $\mathrm{C}$ on the control of parasitic multiplication, and proinflammatory actions of ascorbic acid can be inferred. Previous research carried out by our group ${ }^{30}$ has shown the potentiation of $\mathrm{NO}$ synthesis in infected mice and treated vitamin $\mathrm{C}$, leading to parasitemia control, similar to that observed in the IC group of this study. According to Saeftel et al. $(2001)^{31}$, vitamin C could act by increasing the cytotoxicity of $\mathrm{NK}$ cells, and consequently the level of IFN- $\gamma$, which in turn increases the synthesis and release of nitric oxide by macrophages, these products being essential to combat and control parasitemia early in the acute phase.

However, greater damage to pancreatic tissue was observed in the IC group than in the IW group. Antagonistic actions of vitamin $C$ have already been described by our group ${ }^{30,32}$, since the cytokines synthesized at the beginning of the acute phase simultaneously control the parasitic multiplication, but they generate tissue damage by the formation of peroxynitrite, a substance that damages the cell membrane. ${ }^{33}$

The influence of vitamin $\mathrm{C}$ on glucose blood control was noted, since the IC group had higher glucose concentrations than the IW group at 30- and 60-days post infection. Although these results are not statistically significant, a tendency of vitamin C to maintain higher glucose levels for longer periods can be observed, and consequently interfering with its absorption by cells.

Glucose is the main physiological stimulator for the release of insulin by pancreas $\beta$-cell; however, glucose and ascorbic acid have similar structure. Bergsten et al. (1994) ${ }^{19}$ suggested that ascorbic acid could inhibit the secretion of insulin by hyperpolarization of pancreatic $\beta$ cells and this process is reversible depending on the dose. These observations were confirmed by studies by Johnston and $\mathrm{Yen}^{20}$, who reported that high levels of plasma vitamin $\mathrm{C}$ delay the insulin response after glucose ingestion in normoglycemic individuals, prolonging postprandial hyperglycemia, since high plasma vitamin C concentrations restrict through competition the transfer of glucose in pancreatic $\beta$ cells.

However, parasitic action was also observed, because the trypomastigote forms of T. cruzi have no glucose reserve, and they need to acquire it from the host to survive. ${ }^{34}$ Thus, at 15 days post infection, the animals of the IC and IW groups had lower glucose values than the NC and NW groups, with statistically significant results, since the parasitic peak of the IC group and the rise in the number of trypomastigotes of the IW group had occurred around this day. The intragroup analysis found that groups IW and IC had lower concentration than the baseline, and this result was significant in the IC group.

Although we did not observe an inflammatory process in the portions whose liver fragments were collected for histopathological analysis, we can not omit the infection that occurs in this organ. In similar researches, Combs et al. (2005) ${ }^{17}$ and Hoelscher et al. $(2000)^{35}$ demonstrated severe hypoglycemia in the acute phase of the $T$. cruzi experimental infection. These authors suggested an effect on glucose metabolism possibly due to invasion of the parasite into the liver, causing hepatic inflammation and, consequently, decreased hepatic production of glucose by gluconeogenesis, corroborating our results. 
Probably stimulated by the low glucose concentration, the insulin values in the first 15 days post infection were lower in the IC and IW groups, with statistically significant differences, corroborating studies by Combs et al. $(2005)^{17}$, which found insulin levels decreased in the initial phase of $T$. cruzi infection.

At this time of infection, these animals had increased insulin sensitivity with significant differences in QUICKI values. Some research has found that insulin resistance may be caused by the excessive generation of free radicals stimulated by $T$. cruzi infection. In this context, experimental studies by Nagajyothi et al. (2013) $)^{15}$ and Santos et al. $(2004)^{7}$ found reduced insulin secretion in the acute phase of T. cruzi infection, and the secretion levels remained low until the chronic phase, probably due to pancreatic inflammation with dysfunction of pancreatic $\beta$ cell. With the evolution of the disease to the chronic phase, inflammation of the pancreas causes autonomic dysfunction and compromised pancreatic secretion. ${ }^{8}$

According to Nagajyothi et al. (2010) ${ }^{16}$, hypoglycemia in acute Chagas disease may be a result of the large increase in active cytokines, such as INF- $\gamma$ and TNF- $\alpha$, that induces the animals to decrease food consumption, corroborating the results obtained in this research, where the two groups of infected animals had lower weight gain than the uninfected animals. Therefore, increased catabolic response can be inferred due to the high energy demand required during the infection. ${ }^{36}$

Animals in the IC group presented lower body mass loss than the animals of group IW at 60 days post infection, although without statistically significant difference. This result may suggest beneficial actions of vitamin C in controlling the parasitemia and consequently the synthesis of the proinflammatory cytokines in the final stage of the acute phase. Thus, the presence of higher parasitemia in group IW could induce elevated TNF-a synthesis, inhibiting the lipoprotein lipase activity generating a pyrogenic effect, which can lead to cachexia or severe weight loss ("wasting"), which infers TNF- $\alpha$ as a potent cytokine with anorectic and pro-catabolic role $e^{35,36}$ in the acute phase of Chagas disease, similar to that seen in cancer patients $^{37,38}$. Other cytokines such as IL-1 and IL-6, also synthesized in chagasic infection, mediate an increase in energy expenditure, in addition to mobilizing amino acids and acting on muscle protein catabolism. ${ }^{38}$

The infection by $T$. cruzi can influence the action of leptin ${ }^{39}$, a hormone secreted mainly by adipose tissue. According to Zhang et al. (1994) ${ }^{40}$, leptin can act in regulating intake of foods at the central level, playing an anorectic or satiety role.

Denroche et al. $(2012)^{41}$ demonstrated the role of leptin in the metabolic regulation of glycemia, inhibiting insulin secretion by pancreatic $\beta$ cells of the pancreas, and thus preventing hyperinsulinemia and alterations in glucose homeostasis. In addition to this function, leptin may play an important role in immune control, since it is a pro-inflammatory adipokine, stimulating the synthesis and production of TNF- $\alpha$, and therefore acting on the production of IL-2, IL-6, and IFN- $\gamma$.

Our results indicate that $T$. cruzi infection decreases the capacity to mobilize hepatic glycogen reserves, since an increase in its concentration occurred in group IW in re- 
lation to the uninfected groups and was not influenced by vitamin $\mathrm{C}$ supplementation.

Therefore, the results have suggested that vitamin $\mathrm{C}$ may interfere with glucose metabolism and accentuate the inflammatory process, which may have important physiological repercussions for patients with Chagas disease, both in the acute phase and in its evolution to the chronic phase.

Conflict of Interest: The authors declare that they have no conflict of interest.

\section{REFERENCES}

1. Hotez PJ, Molyneux DH, Fenwick A, Ottesen E, Ehrlich Sachs S, Sachs JD. Incorporating a rapidimpact package for neglected tropical diseases with programs for HIV/AIDS, tuberculosis, and malaria. PLoS Med. 2006;3(5):e102. doi: 10.1371/journal.pmed.0030102.

2. Dias JCP, Human Chagas Disease and Migration in the Context of Globalization: Some Particular Aspects. Journal of Tropical Medicine. 2013:789758

3. Carvalho NC, Atala MM, Leite RM, Yasuda MA. Manual de atendimento a pacientes com Doença de Chagas: atenção básica 2014/2015. São Paulo (SP): Faculdade de Medicina da Universidade de São Paulo; 2018.

4. Reis GA. Evasion of immune responses by Trypanosoma cruzi, the etiological agent of Chagas disease. Braz J Med Biol Res. 2011;44(2):84-90. doi: 10.1590/-879X2011007500005.

5. Núñez Sellés AJ. Terapia antioxidante, estrés oxidativo y productos antioxidantes: retos y oportunidades. Rev Cuba Salud Pública. 2011;37(Supl 5):644-60.

6. Ferreira ALA, Correa CR, Freire CMM, Moreira PL, Berchieri-Ronchi CB, Reis RAS, Nogueira CR.Síndrome metabólica: atualização de critérios diagnósticos e impacto do estresse oxidativo na patogênese*. Rev Bras Clin Med. São Paulo, 2011;9(1):54-61.

7. Santos VM, Lima MA, Cabrine-Santos M, Marquez DS, Pereira GA, Lages-Silva E, et al. Functional and histopathological study of the pancreas in hamsters (Mesocricetus auratus) infected and reinfected with Trypanosoma cruzi. Parasitol Res. 2004;94(2):125-33. doi: 10.1007/s00436004-1183-8.

8. Saldanha JC, Santos VM, Reis MA, Cunha DF, Teixeira VPA. Morphologic and morphometric evaluation of pancreatic islets in chronic Chagas' disease. Rev Hosp Clín Fac Med Univ São Paulo. 2001;56(5):131-8. doi: 10.1590/S0041-87812001000500001.

9. Oliveira LC, Juliano Y, Novo NF, Neves MM. Blood glucose and insulin response to intravenous glucose by patients with chronic Chagas' disease and alcoholism. Braz J Med Biol Res. 1993;26(11):1187-90.

10. Santos VM, Cunha SFC, Teixeira VPA, Monteiro JP, Santos JAM, Santos TAM, et al. Frequência de diabetes mellitus e hiperglicemia em mulheres chagásicas e não-chagásicas. Rev Soc Bras Med Trop. 1999;32(5):489-96. doi: 10.1590/S0037-86821999000500004.

11. Guariento ME, Saad MJ, Muscelli EO, Gontijo JA. Heterogenous insulin response to an oral glucose load by patients with the indeterminate clinical form of Chagas' disease. Braz J Med Biol Res. 1993;26(5):491-5.

12. Geraix J, Ardisson LP, Marcondes-Machado J, Pereira PC. Clinical and nutritional profile of individuals with Chagas disease. Braz J Infect Dis. 2007;11(4):411-4. doi: 10.1590/S141386702007000400008.

13. Navarro EC, Abreu MM, Tavares FC, Corrente JE, Arruda CM, Pereira PCM. Indeterminate form of Chagas' disease and metabolic syndrome: a dangerous combination. Am J Med Med Sci. 2013;3(4):68-73. doi: 10.5923/j.ajmms.20130304.03. 
14. Tanowitz HB, Amole B, Hewlett D, Wittner M. Trypanosoma cruzi infection in diabetic mice. Trans R Soc Trop Med Hyg. 1988;82(1):90-3.

15. Nagajyothi F, Kuliawat R, Kusminski CM, Machado FS, Desruisseaux MS, Zhao D, et al. Alterations in glucose homeostasis in a murine model of Chagas disease. Am J Pathol. 2013;182(3):88694. doi: 10.1016/j.ajpath.2012.11.027.

16. Nagajyothi F, Zhao D, Machado FS, Weiss LM, Schwartz GJ, Desruisseaux MS, et al. Crucial role of the central leptin receptor in murine Trypanosoma cruzi (Brazil strain) infection. J Infect Dis. 2010;202(7):1104-13. doi: 10.1086/656189.

17. Combs TP, Nagajyothi, Mukherjee S, de Almeida CJ, Jelicks LA, Schubert W, et al. The adipocyte as an important target cell for Trypanosoma cruzi infection. J Biol Chem. 2005 24;280(25):2408594. doi: 10.1074/jbc.M412802200.

18. Parsey RV, Matteson DR. Ascorbic acid modulation of calcium channels in pancreatic beta cells. J Gen Physiol. 1993;102(3):503-23. doi: 10.1085/jgp.102.3.503.

19. Bergsten P, Moura AS, Atwater I, Levine M. Ascorbic acid and insulin secretion in pancreatic islets. J Biol Chem. 1994;269(2):1041-5.

20. Johnston CS, Yen MF. Megadose of vitamin C delays insulin response to a glucose challenge in normoglycemic adults. Am J Clin Nutr. 1994;60(5):735-8. doi: 10.1093/ajcn/60.5.735.

21. Cunningham JJ. The Glucose/Insulin System and Vitamin C: Implications in Insulin-Dependent Diabetes Mellitus. Journal of the American College of Nutrition, 1998 17(2):105-108

22. Martins LP, Marcili A, Castanho RE, Therezo AL, Oliveira JC, Suzuki RB,et al. MA. Rural Triatoma rubrovaria from southern Brazil harbors Trypanosoma cruzi of lineage IIc. Am J Trop Med Hyg. 2008 79(3):427-34.

23. Gusmão AS, Castanho $\underline{\mathrm{RE}}$, Andrade RF, Farsetti CM, Mathias AB, Therezo AL, et al.Vitamin C effects in mice experimentally infected with Trypanosoma cruzi QM2 strain. Rev Soc Bras Med Trop . 2012;45(1):51-4. doi: 10.1590/S0037-86822012000100010.

24. Lopes ES, Prado Junior JC. A influência da cepa Y de Trypanosoma cruzi no coração em ratos wistar machos submetidos ao processo de adrenalectomia. Biodiversidade. 2007;6(1):62-76.

25. Ayala JE, Bracy DP, McGuinness OP, Wasserman DH. Considerations in the design of hyperinsulinemic-euglycemic clamps in the conscious mouse. Diabetes. 2006;55(2):390-7. doi: 10.2337/ diabetes.55.02.06.db05-0686.

26. Katz A, Nambi SS, Mather K, Baron AD, Follmann DA, Sullivan G, Quon MJ. Quantitative Insulin Sensitivity Check Index: A Simple, Accurate Method for Assessing Insulin Sensitivity In Humans. The Journal of Clinical Endocrinology \& Metabolism. 2000;85(7):2402-10

27. Bidinotto PM, Souza RHS, Moraes G. Hepatic glycogen in eight tropical freshwater teleost fish: procedure for field determinations of microsamples. Bol Téc CEPTA. 1997; 10:53-60.

25. Barreiros AL, David JM, David JP. Estresse oxidativo: relação entre geração de espécies reativas e defesa do organismo. Quím Nova. 2006;29(1):113-23. doi: 10.1590/S0100-40422006000100021.

28. Maçao LB, Wilhelm Filho D, Pedrosa RC, Pereira A, Backes P, Torres MA, et al.Antioxidant therapy attenuates oxidative stress in chronic cardiopathy associated with Chagas' disease. Int J Cardiol. 2007 15;123(1):43-9. doi: 10.1016/j.ijcard.2006.11.118.

29. Duarte TL, Lunec J. Review: when is an antioxidant not an antioxidant? A review of novel actions and reactions of vitamin C. Free Radic Res. 2005;39(7):671-86. doi: 10.1080/10715760500104025.

30. Castanheira J, Castanho RE, Rocha H, Jr., Pagliari C, Duarte MI, Therezo AL, et al.Paradoxical effects of vitamin C in Chagas disease. Parasitol Int. 2018;67(5):547-55. doi: 10.1016/j. parint.2018.05.002.

31. Saeftel M, Fleischer B, Hoerauf A. Stage-dependent role of nitric oxide in control of Trypanosoma cruzi infection. Infect Immun. 2001;69(4):2252-9. doi: 10.1128/IAI.69.4.2252-2259.2001. 
32. Tieghi TM, Manca CC, Garcia LC, Castanho RE, Therezo AL, Frei F, et al.Evaluation of antioxidant therapy in experimental Chagas disease. Rev Soc Bras Med Trop. 2017;50:184-93. doi: 10.1590/0037-8682-0451-2016.

33. Gutierrez FR, Mineo TW, Pavanelli WR, Guedes PM, Silva JS. The effects of nitric oxide on the immune system during Trypanosoma cruzi infection. Mem Inst Oswaldo Cruz. 2009;104(Supl 1):236-45. doi: 10.1590/S0074-02762009000900030.

34. Cazzulo JJ. Aerobic fermentation of glucose by trypanosomatids. FASEB J. 1992;6(13):3153-61. doi: 10.1096/fasebj.6.13.1397837.

35. Hölscher C, Mohrs M, Dai WJ, Köhler G, Ryffel B, Schaub GA, et al. F. Tumor necrosis factor alpha-mediated toxic shock in Trypanosoma cruzi-infected interleukin 10-deficient mice. Infect Immun. 2000 68(7):4075-83. doi: 10.1128/iai.68.7.4075-4083.2000.

36. Keusch GT. The history of nutrition: malnutrition, infection and immunity. J Nutr. 2003;133(1):336S-40S. doi: 10.1093/jn/133.1.336S.

37. Laviano A, Meguid MM, Rossi-Fanelli F. Cancer anorexia: clinical implications, pathogenesis, and therapeutic strategies. Lancet Oncol. 2003;4(11):686-94. doi: 10.1016/S1470-2045(03)01247-6.

38. Matthys P, Billiau A. Cytokines and cachexia. Nutrition. 1997;13(9):763-70. doi: 10.1016/S08999007(97)00185-8.

39. Andrade ZA, Silva HR. Parasitism of adipocytes by Trypanosoma cruzi. Mem Inst Oswaldo Cruz. 1995;90(4):521-2. doi: 10.1590/s0074-02761995000400018.

40. Zhang Y, Proenca R, Maffei M, Barone M, Leopold L, Friedman JM. Positional cloning of the mouse obese gene and its human homologue. Nature. 1994;372(6505):425-32. doi: $10.1038 / 372425 \mathrm{a} 0$.

41. Denroche HC, Huynh FK, Kieffer TJ. The role of leptin in glucose homeostasis. J Diabetes Investig. 2012;3(2):115-29. doi: 10.1111/j.2040-1124.2012.00203.x.

\section{DAdos dos AUTORES}

\section{Julia Castanheira}

Mestre em saúde e envelhecimento pela Faculdade de Medicina de Marília, Marília/SP - Brasil.

\section{Renata Facina Santos}

Graduada em medicina. Residente no Hospital Lauro de Souza Lima, Bauru/SP - Brasil. reefacina@ gmail.com

\section{Letícia Alvetti}

Graduada em medicina. Residente na Faculdade de Medicina de Marília, Marília/SP - Brasil. leaalvetti@yahoo.com

\section{ROBERTo Castanho}

Doutor em biotecnologia apliacada a farmácia. Docente da disciplina de parasitologia na Faculdade de Medicina de Marília, Marília/SP - Brasil. castanho@famema.br

\section{Hamilton Rocha Junior}

Graduado em medicina. Médico coordenado do Pronto Socorro do Hospital Madre Teodora, Campinas/SP - Brasil. hamiltonjunior2006@hotmail.com 


\section{Altino Therezo}

Graduado em medicina. Doutor em anatomia patológica. Docente da disciplina de anatomia patológica na Faculdade de Medicina de Marília, Marília/SP - Brasil. altinoth@hotmail.com

\section{Eduardo Chagas}

Programa de Pós-Graduação em Interações Estruturais e Funcionais em Reabilitação e Centro Interdisciplinar em Diabetes (CENID), Universidade de Marília (UNIMAR), Marília - São Paulo - Brasil. efbchagas@hotmail.com

\section{Luciamare Perinetti Alves Martins}

Luciamare Perinetti Alves Martins Doutora em biotecnologia aplicada a farmácia. Docente da disciplina de parasitologia da Faculdade de Medicina de Marília, Marília/SP - Brasil.

luciamarepam@gmail.com

Financial support:This study was funded by Fundação de Amparo à Pesquisa do Estado de São Paulo (FAPESP): Grant n 2013/22703-3 and no 2016/21260-9. 